\title{
Nurturing resilient forest biodiversity: nest webs as complex adaptive systems
}

\author{
$\underline{\text { José Tomás Ibarra }}^{1,2}$, Kristina L. Cockle $^{3,4}, \underline{\text { Tomás A. Altamirano }}^{3,5}$, Yntze van der Hoek $^{6,7}$, Suzanne W. Simard $^{3}$, Cristián Bonacic $^{8}$ \\ and Kathy Martin ${ }^{3,9}$
}

\begin{abstract}
Forests are complex adaptive systems in which properties at higher levels emerge from localized networks of many entities interacting at lower levels, allowing the development of multiple ecological pathways and processes. Cavity-nesters exist within networks known as "nest webs" that link trees, excavators, e.g. woodpeckers, and nonexcavators (many songbirds, ducks, raptors, and other organisms) at the community level. We use the idea of panarchy (interacting adaptive cycles at multiple spatio-temporal scales) to expand the nest web concept to levels from single tree to biome. We then assess properties of nest web systems (redundancy, heterogeneity, memory, uncertainty, and nonlinearity) using examples from our studies in temperate, subtropical, and tropical forests of the Americas. Although nest webs from Chile, Canada, Argentina, and Ecuador have independent evolutionary histories, structures, and disturbance regimes, they share the main properties of complex adaptive systems. Heterogeneity, redundancy, and memory allow nest web systems to absorb some degree of disturbance without undergoing a regime shift; that is, without changing their basic structures and functions, i.e., the system's identity. Understanding nest webs as complex adaptive systems will inform management practices to nurture the resilience of forest biodiversity in the face of local, regional, and global social-ecological changes.
\end{abstract}

Key Words: Americas; cavity-using vertebrates; complexity; forest management; memory; panarchy; resilience; social-ecological systems

\section{INTRODUCTION}

The search for holistic, yet scientifically sound, whole-system models in forest ecology and conservation has led to an increasing interest in complex system science (Parrott and Meyer 2012, Messier et al. 2013, Filotas et al. 2014). Historically, forest biodiversity has been assessed and managed through the lens of a single dominant objective, which can result in counterproductive conservation and management practices (Puettmann et al. 2009). For example, fire suppression policies to control the loss of greentree forests led to unpredicted declines in the red-listed Blackbacked Woodpecker (Picoides arcticus; Hutto 2006). Forest ecosystems are, in fact, prototypical examples of complex adaptive systems (CAS) in which properties at higher levels (Gunderson and Holling 2002, Messier and Puettmann 2011, Parrott and Meyer 2012), emerge from self-organized networks of many entities (individuals, species, guilds) interacting at lower levels (Levin 1998, Strogatz 2001, Simard et al. 2013). Gunderson and Holling (2002) proposed the concept of panarchy as a framework of rules that captures the evolutionary characteristics of adaptive cycles (Table 1), while allowing hierarchical nesting of these cycles across spatial and temporal scales. Panarchy can be used to describe how complex social-ecological systems, such as forests, are interlinked in multilevel adaptive cycles of growth $(\mathrm{r})$, conservation $(\mathrm{K})$, release $(\Omega)$, and reorganization ( $\alpha$; Table 1$)$. This proposal by Gunderson and Holling (2002), triggered a major discussion about the role of panarchy in forest resilience, the latter defined as the capacity of forests to adaptively persist following anthropogenic and natural disturbances while retaining their essential structures and functions, i.e. system's identity (Holling 1973, Messier et al. 2013).

About 1900 species of birds ( 18\% of all birds) and many other vertebrates use tree cavities for nesting and roosting, constituting a key component of forest biodiversity that is traditionally managed at the stand or single-tree level (Bunnell and Dunsworth 2009, Van der Hoek et al. 2017). Cavity-users interact in networks known as "nest webs," conventionally viewed as hierarchical and commensal, with resource (cavity) flow from trees facilitated by excavators, e.g., woodpeckers, to nonexcavators, e.g., many songbirds, ducks, raptors, and other organisms (Martin and Eadie 1999, Martin et al. 2004). Excavators are considered to facilitate nonexcavators, which then compete amongst themselves for the cavity resource (Fig. 1). The simplicity of the hierarchical nest web model encouraged researchers to initiate community-level nest web studies in many forests globally, allowed us to analyze cavity-nesting communities as bi- or tri-partite ecological networks, and facilitated communication with forest managers and the public (Martin et al. 2004, Cockle and Martin 2015, Ruggera et al. 2016, Altamirano et al. 2017, Manikandan and Balasubramanian 2018).

Outside the conventional framework, nest webs experience feedback loops among guilds and interact with other networks at multiple levels, such that a whole-system view could be important for management (Floyd and Martin 2016, Ibarra et al. 2017a). In

${ }^{1}$ ECOS (Ecology-Complexity-Society) Laboratory, Center for Local Development (CEDEL) \& Center for Intercultural and Indigenous Research (CIIR), Villarrica Campus, Pontificia Universidad Católica de Chile, Villarrica, Chile, ${ }^{2}$ Millennium Nucleus Center for the Socioeconomic Impact of Environmental Policies (CESIEP) \& Center of Applied Ecology and Sustainability (CAPES), Pontificia Universidad Católica de Chile, Santiago, Chile, ${ }^{3}$ Department of Forest and Conservation Sciences, University of British Columbia, Vancouver, British Columbia, Canada, ${ }^{4}$ Instituto de Biología Subtropical (IBS-CONICET-UNaM), Puerto Iguazú, Argentina, ${ }^{5}$ ECOS (Ecology-Complexity-Society) Laboratory, Center for Local Development (CEDEL), Villarrica Campus, Pontificia Universidad Católica de Chile, Villarrica, Chile, ${ }^{6}$ Universidad Regional Amazónica IKIAM, Tena, Ecuador, ${ }^{7}$ Dian Fossey Fund International, Musanze, Rwanda, ${ }^{8}$ Department of Ecosystems and The Environment \& School of Veterinary Medicine, Pontificia Universidad Católica de Chile, Santiago, Chile, ${ }^{9}$ Environment and Climate Change Canada, Pacific Wildlife Research Centre, Delta, British Columbia, Canada 
Table 1. Panarchy, adaptive cycles, and properties of nest webs as complex adaptive systems (CAS).

\begin{tabular}{|c|c|}
\hline Term & Definition in a nest web context \\
\hline Panarchy & $\begin{array}{l}\text { Nest webs exhibit adaptive cycles at four interacting levels: (1) the single cavity-tree, (2) the integrated community of cavity } \\
\text { nesters, i.e., a nest web of a single forest type, (3) the landscape mosaic of forests, i.e., nest webs that interact across forest types } \\
\text { within a biome, and (4) the regional pattern of nest webs, i.e., mosaics of nest webs that interact across landscapes through, for } \\
\text { example, colonization, range expansions, and other changes that are affected by broad-scale cycles. The lower level cycles are } \\
\text { dynamic, adaptive, and sensitive to small changes with potential for creative transformations. The larger level cycles are generally } \\
\text { slower, stable, and robust, constraining the system against the dynamism of the smaller, generally faster cycles. Continuous } \\
\text { shuffling through these interacting loops provides the opportunity for novel assortments and configurations in the ecosystem. }\end{array}$ \\
\hline Adaptive cycle & $\begin{array}{l}\text { The adaptive cycle is a representation of system dynamics at a particular spatial and temporal scale. The system at that scale } \\
\text { cycles through four sequential stages, from rapid growth }(\mathrm{r}) \text { such as when a population, e.g., of a cavity nester, grows, to } \\
\text { conservation }(\mathrm{K}) \text { such as when the population reaches carrying capacity, to release }(\Omega) \text { such as when the population becomes } \\
\text { overcrowded and vulnerable to reorganization }(\alpha) \text { such as when uncertainty can lead to novel adjustments. Each sequential stage } \\
\text { is present at every adaptive cycle. The adaptive cycle is shaped by three attributes: (1) the inherent potential for the system to } \\
\text { change, }(2) \text { the degree of internal control or connectedness of the system, and (3) the adaptive capacity and resilience to } \\
\text { unexpected shocks. }\end{array}$ \\
\hline Redundancy & $\begin{array}{l}\text { Degree to which organisms resemble each other in their functional roles. In nest web systems, the degree to which decay } \\
\text { organisms, tree species, cavity nesters, and forest types produce tree cavities and nest webs with similar characteristics. }\end{array}$ \\
\hline Heterogeneity & $\begin{array}{l}\text { Heterogeneity is expressed by the uneven nature of interacting entities and their behaviors, spatial location, structural } \\
\text { organization, and history. In nest web systems, interacting entities (plants, fungi, animals, forests, people) are heterogenously } \\
\text { distributed in space, contributing to spatial heterogeneity in tree-decay processes, cavity availability, and nest web diversity. }\end{array}$ \\
\hline Memory & $\begin{array}{l}\text { Record of historical events that continues to influence compositional, structural, and functional states of the system. Memory of } \\
\text { a nest web includes, for example, habitat legacies: long-lived system entities such as very old trees, cavities, and forest patches, } \\
\text { whose presence and influence extends over a long time. }\end{array}$ \\
\hline $\begin{array}{l}\text { Uncertainty and } \\
\text { nonlinearity }\end{array}$ & $\begin{array}{l}\text { Uncertainty is associated with nonlinear dynamics and incomplete knowledge of the system. Sources of uncertainty, e.g., crucial } \\
\text { nonmeasured variables, reduce our ability to predict the future state of nest web systems. They also generate variability that may } \\
\text { be amplified by feedback loops, leading to the emergence of novel relations or structures. }\end{array}$ \\
\hline
\end{tabular}

addition to facilitation, interactions among excavators and nonexcavators can include competition and predation (Blanc and Walters 2008a, Wesołowski 2017, Wiebe 2017). Cavity-nesters disperse seeds of future nest trees and spores of the wood-decay fungi that facilitate cavity formation (Lonsdale et al. 2008, Holbrook and Loiselle 2009, Jusino et al. 2016, Tella et al. 2016, Speziale et al. 2018), but some species may also reduce recruitment of cavity trees through seed predation (Renton 2001). Underground, a network of mycorrhizal fungi connects current and future cavity trees, promoting recruitment (Simard et al. 2013). Multiscale linkages between nest webs and other networks, including social-ecological networks in which decision makers and the general public interact, give rise to structural and dynamic emergent properties of a complex adaptive system (Filotas et al. 2014).

In this synthesis paper we show how complex system science can provide a holistic, unifying model for the study of nest webs globally. We first use panarchy to represent a hierarchy of adaptive cycles, then review properties of CAS (redundancy, heterogeneity, memory, uncertainty, and nonlinearity) in nest web systems (Table 1). We draw on examples from our long-term studies across a gradient from mega-diverse tropical and subtropical forests at lower latitudes to species-poor temperate systems at higher north and south latitudes in the Americas (Table 2, Fig. 2). Finally, we link the properties of nest webs to potential forest management practices. We do this by integrating forestry into a holistic framework with the goal of helping nurture the resilience of complex adaptive nest webs in the face of local, regional, and global changes.

\section{PANARCHY IN NEST WEBS}

A panarchy (linked multilevel interactions) is a representation of a hierarchy of adaptive cycles (Table 1). We describe below the characteristics of each adaptive cycle in nest webs, from the smallest to the largest level (Fig. 3).

\section{Single cavity-tree}

During the growth (r) stage a seed germinates, the seedling is colonized by mycorrhizal fungi (facilitating growth and survival), and grows to a suitable size, age, and decay status for a cavity to form, for example, by excavation in a dead branch (Fig. 1; DeGraaf and Shigo 1985, Lindenmayer et al. 1993, Koch et al. 2008, Blanc and Martin 2012, Simard et al. 2013). In the conservation stage $(\mathrm{K})$, micro-organisms slowly increase the size of the cavity (Edworthy and Martin 2014, Zheng et al. 2016), and it is occupied by a series of cavity-nesting vertebrates (Edworthy et al. 2017) that may also disperse seeds or fungi to and from the nest site (Simard et al. 2013, Jusino et al. 2016, Tella et al. 2016). Over time, increasing size and advancing decay might slowly increase vulnerability of the cavity to depredation and usurpation, making it less suitable for nesting vertebrates (Wesołowski and Rowiński 2004, Zhu et al. 2012, Pakkala et al. 2017). As decay advances through the cavity-tree, the system eventually reaches a state of vulnerability to stress or disturbance; for example, the cavity-bearing branch may break off, leading to a rapid release $(\Omega)$ as the tree becomes temporarily unsuitable for nesting. This may be followed by reorganization $(\alpha)$ that can lead to novel responses, for example, if the falling branch creates a new cavity in the tree stem, or if the tree itself falls, exiting the system, and another seedling takes its place, moving the system to a new " $r$ " stage. These conditions are highly unpredictable and uncertain. For example, the species of seedling that replaces the old-growth tree will be influenced by the seeds and mycorrhizal propagules dispersed by prior cavity occupants. Because adaptive cycles occur simultaneously (but asynchronously) in multiple individual trees throughout a forest stand, they combine to form the adaptive cycle at the adjacent higher level (nest web community, below). 
Fig. 1. A simple conventional model of nest web (grey box) with positive (black) and negative (yellow) interactions among species (Martin and Eadie 1999). Cavities flow (straight black arrows) from trees to cavity producers, i.e., excavators or decay, to nonexcavators, which compete amongst themselves for the limited cavity resource (straight yellow arrows). Weaker links are shown with broken lines. Arrows outside the grey box highlight several important feedback loops beyond the conventional nest web model.

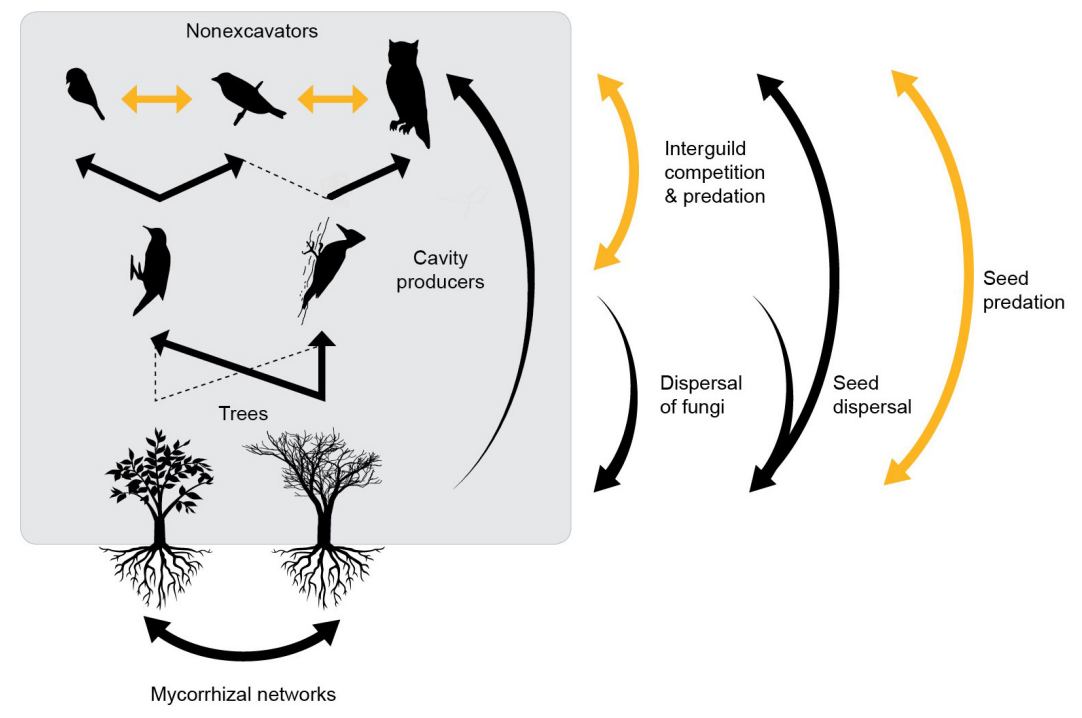

At the transition from the conservation stage $(\mathrm{K})$ to release $(\Omega)$ and the transition from reorganization $(\alpha)$ to growth (r), the adaptive cycle can be transformed, affecting the adaptive cycle at the adjacent higher level. For example, cutting a large tree for timber (a common practice at our study of social-ecological systems in South America) will not only stop the cycles of cavity production in that tree, but will also impact seed dispersal- and mycorrhizal networks at the community level (next adaptive cycle).

\section{Community of cavity nesters}

At the community level, we propose that the growth (r) stage is characterized by initial recruitment of short-lived, mostly excavated cavities in fast-growing pioneer tree species in early successional forest (Cockle et al. 2017). Initially, most cavities are small, low, and similar to one another, and are used by a limited set of small-bodied, disturbance-tolerant, cavity-nesting animals (Dantas Oliveira 2015). The conservation stage (K) is reached as the forest gets older and begins to include shade-tolerant tree species with longer lasting cavities, as well as large dead trees, such that a wider range of cavity types and sizes can support a diverse nest web of excavators and nonexcavators (Cockle et al. 2019a). At this stage, the nest web may be exposed to rapid release $(\Omega)$ because the forest is increasing in structural complexity due to individual tree mortality (from insects, disease, fire, drought, etc.) and gap-phase dynamics (Franklin and Van Pelt 2004, Zenner 2004, Caviedes and Ibarra 2017). As the forest transitions to oldgrowth structures during the reorganization $(\alpha)$ stage, the nest web will comprise a diverse suite of tree and vertebrate species, including old-growth specialists that require large decay-formed cavities in living trees, as well as large cavity-nesting seed-
Fig. 2. Species numbers of birds (grey bar), cavity-nesting birds (brown bar), and trees (green bar) in our study sites across the Americas. These sites represent a gradient of forests from relatively species-poor temperate systems at higher latitudes to species-rich subtropical and tropical forest areas at lower latitudes (closer to the equator). The distribution of forested areas in the continent is shown in green.

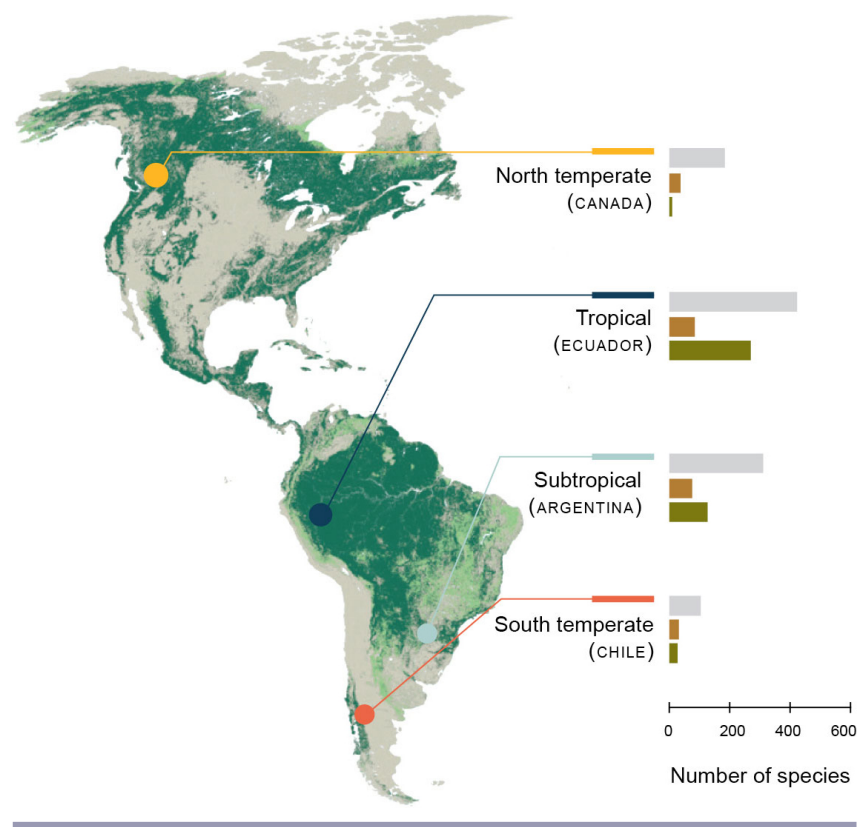


Table 2. General attributes of forest ecosystems presented in this paper.

\begin{tabular}{|c|c|c|c|c|}
\hline Forest ecosystem & $\begin{array}{l}\text { North temperate forest } \\
(\text { Canada })^{1}\end{array}$ & Tropical forest (Ecuador) $^{2}$ & Subtropical forest (Argentina) ${ }^{3}$ & South temperate forest (Chile) ${ }^{4}$ \\
\hline $\begin{array}{l}\text { Geographic } \\
\text { location } \\
\text { (coordinates) }\end{array}$ & $52^{\circ} 08^{\prime} \mathrm{N}, 122^{\circ} 08^{\prime} \mathrm{W}$ & $0^{\circ} 59^{\prime} \mathrm{S}, 77^{\circ} 48^{\prime} \mathrm{W}$ & $26^{\circ} 38^{\prime} \mathrm{S}, 54^{\circ} 07^{\prime} \mathrm{W}$ & $39^{\circ} 16^{\prime} \mathrm{S}, 71^{\circ} 48^{\prime} \mathrm{W}$ \\
\hline Elevation (m asl) & $800-920$ & $300-1200$ & $520-700$ & $220-1400$ \\
\hline Forest type & Interior Douglas-fir forest & $\begin{array}{l}\text { Amazonian tropical lowland and } \\
\text { Piedmont rainforest }\end{array}$ & Atlantic forest & Andean temperate rainforest \\
\hline $\begin{array}{l}\text { Major recent } \\
\text { disturbances }\end{array}$ & $\begin{array}{l}\text { Wildfire, insect outbreak, } \\
\text { clear-cut and partial cut } \\
\text { logging, followed by } \\
\text { planting of native trees }\end{array}$ & $\begin{array}{l}\text { Forest clearing for agriculture/ } \\
\text { livestock, clear-cut and partial cut } \\
\text { logging, defaunation through } \\
\text { overharvesting }\end{array}$ & $\begin{array}{l}\text { Forest clearing for agriculture/ } \\
\text { livestock/exotic tree plantations, } \\
\text { highgrade logging, defaunation } \\
\text { through overharvesting }\end{array}$ & $\begin{array}{l}\text { Wildfire, volcanic eruption, } \\
\text { forest clearing for agriculture/ } \\
\text { livestock, exotic tree plantations }\end{array}$ \\
\hline $\begin{array}{l}\text { Current social- } \\
\text { ecological context }\end{array}$ & $\begin{array}{l}\text { Forests embedded in mosaic } \\
\text { of small lakes, and native } \\
\text { grasslands, maintained by } \\
\text { low intensity fires and cattle } \\
\text { grazing. Commercial and } \\
\text { private land use for forestry, } \\
\text { agriculture, recreational } \\
\text { hunting, and fishing. } \\
\text { Primarily public land } \\
\text { tenure, long-term forestry } \\
\text { and grazing leases. } \\
\text { Increasing intensity and } \\
\text { frequency of disturbance } \\
\text { processes due to climate } \\
\text { warming and landscape } \\
\text { management. }\end{array}$ & $\begin{array}{l}\text { Mosaic of old-growth forest, } \\
\text { secondary forest, and selectively } \\
\text { logged forest, agroforestry } \\
\text { practices ("chakras"). Increasing } \\
\text { urbanization, intensive agriculture, } \\
\text { and infrastructure development. } \\
\text { Selective logging and illegal } \\
\text { hunting remain an issue. } \\
\text { Subsistence hunting decreasing. } \\
\text { Production and export (cacao, Ilex } \\
\text { guayusa) increasing. High poverty. } \\
\text { Environmental and territorial } \\
\text { planning are undeveloped. }\end{array}$ & $\begin{array}{l}\text { Forest embedded in mosaic of } \\
\text { small-holder farms and large } \\
\text { multinational tree plantations, } \\
\text { high poverty and history of } \\
\text { social oppression, low levels of } \\
\text { land tenure, lawlessness, farmers } \\
\text { use forest for wood, firewood, } \\
\text { water, illegal hunting, } \\
\text { investment. Indigenous Mbya } \\
\text { people marginalized and } \\
\text { struggling to sustain their } \\
\text { livelihoods. }\end{array}$ & $\begin{array}{l}\text { Forest primarily on mountain } \\
\text { slopes, interspersed with } \\
\text { grasslands and shrublands. } \\
\text { Valleys occupied by agricultural } \\
\text { fields, native forest fragments of } \\
\text { diverse sizes, exotic tree } \\
\text { plantations, lakes and rivers. } \\
\text { Agroforestry systems from } \\
\text { indigenous Mapuche } \\
\text { communities, campesinos, and } \\
\text { new settlers are interspersed with } \\
\text { large ranches and, increasingly, } \\
\text { urban areas. }\end{array}$ \\
\hline
\end{tabular}

Fig. 3. In this panarchy model of nest web patterns and processes interacting across spatial and temporal scales, the continuous reshuffling within adaptive cycles at each level, and the constant feedback across levels, allows the nest web to constantly adapt and evolve to the changing conditions of forests around the world (see Table 1 for details).

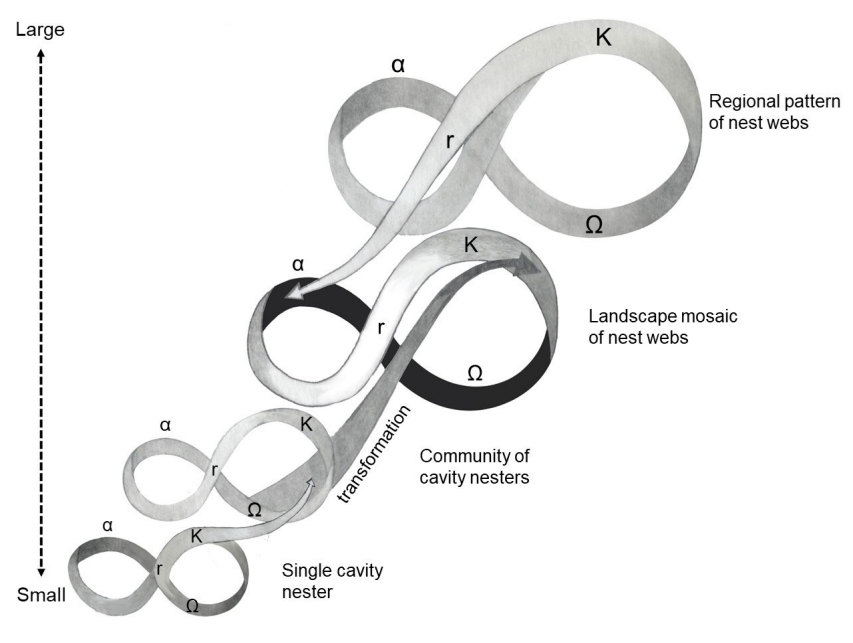

dispersers, e.g., toucans and parrots, and large-seeded animaldispersed trees (Tabarelli et al. 1999, Lammertink et al. 2019). This process of change, with the evolving community of trees, excavators, and nonexcavators, constrains and stabilizes the smaller and faster processes of recruitment, decay, and loss of cavities at the single nest-tree level. The nest web is also sensitive to and evolves according to processes that influence the species pool and disturbance regimes at higher level adaptive cycles (landscape and regional levels, below; Cockle et al. 2019a, $b$ ).

\section{Landscape mosaic of nest webs}

At the landscape level, variation in forest disturbance and regeneration patterns and processes lead to a shifting mosaic of forest patches (stands) along with growth (r) or recruitment of a range of nest web communities. Fire and other social-ecological disturbance regimes, driven for instance by climate change, market forces, and policy pressures, create patches of various sizes and age class distributions that generally follow a scale-free pattern (Perry et al. 2011, Filotas et al. 2014), which we hypothesize will influence the landscape pattern of nest web communities. The conservation $(\mathrm{K})$ stage in the community of interacting nest webs occurs when the shifting mosaic of forests across the landscape reaches a dynamic equilibrium. Rapid release $(\Omega)$ of the nest web structure can occur when a large scale, infrequent disturbance causes extensive tree mortality, shifting forest composition and age, as when mountain pine beetle (Dendroctonus ponderosae) kills extensive areas of lodgepole pine forest across the British Columbia landscape on a return interval 
of 30-40 years (Alfaro et al. 2010, Simard et al. 2013, Cockle and Martin 2015). In the most recent outbreak, death of lodgepole pine (Pinus contorta) and release of trembling aspen (Populus tremuloides), for example, caused a rapid reorganization $(\alpha)$ of the community of nest webs across the landscape. This rapid reorganization at the landscape level, coupled with the changing climate, led to a high degree of unpredictability and uncertainty in the recovering forest structure, and fluctuations in abundance and fecundity of several species in the nest web (Edworthy et al. 2011, Norris and Martin 2014). The evolving mosaic of forests and interacting nest webs across the landscape influences the composition of nest webs at the (lower) stand level, and vice versa (Drever and Martin 2007, Norris and Martin 2014). As a consequence of the landscape level disturbance, release $(\Omega)$ and reorganization $(\alpha)$ lead to reorganization of the nest web, allowing the possibility of novel species and links (Martin et al. 2006, Cockle and Martin 2015).

\section{Regional mosaic of nest web landscapes}

At the regional level, historical evolutionary processes, the distribution of biomes according to climate, and other socialecological (including economic and political) forces have determined the distribution of cavity-nesting species and their interactions in nest webs across latitudinal and longitudinal gradients leading to growth (r) of different nest web landscapes in boreal, temperate, and tropical regions (Bai et al. 2003, Martin et al. 2004, Cooke and Hannon 2011, Cockle et al. 2011, 2019b, Altamirano et al. 2017). A relatively stable climate in the past centuries may have resulted in conservation $(\mathrm{K})$ of the distribution of nest webs across the Americas. However, with recent changes in land-use patterns, as well as species invasions and widespread wildfires, and concomitant changes in forest cover, health, and tree species ranges, the global distribution of nest webs is vulnerable to rapid shifts or releases $(\Omega)$. Climate change, defaunation, and rapid expansion of human-modified landscapes, including land intended for satisfying an increasing demand for timber, paper, or pasture land, and replacement of large proportions of native forest with non-native tree plantations, will likely lead to massive reorganization $(\alpha)$ of nest webs across regions (Tabarelli et al. 1999, Harley 2011, Ibarra and Martin 2015, Van der Hoek et al. 2017).

\section{PROPERTIES OF NEST WEBS AS COMPLEX ADAPTIVE SYSTEMS}

\section{Redundancy and heterogeneity}

Redundancy describes the replication of pathways in a system, and is determined by the number of entities that perform a particular function similarly (Walker 1992, Biggs et al. 2015). Redundant entities in nest web systems can include, for example, individual cavities and species (plants, excavators, decay organisms, seed dispersers, mycorrhizal fungi). Changes in cavity supply are likely to have the greatest impact on nest webs where cavities are scarce (low redundancy) and limit breeding density, e.g., subtropical Atlantic Forest (Cockle et al. 2010, Lammertink et al. 2019). Across species, the cavities produced by excavators in our systems vary in size by an order of magnitude, from $3.1 \mathrm{~cm}^{2}$ entrance area (12 g Ochre-collared Piculet Picumnus temminckii) to $225 \mathrm{~cm}^{2}(260 \mathrm{~g}$ Magellanic Woodpecker Campephilus magellanicus). Low species redundancy occurs in the south temperate forest (Chile), where only four species of excavators produce cavities, overlapping very little in size, i.e., restricted niche available to nonexcavators (Ibarra and Martin 2015, Altamirano et al. 2017); high redundancy occurs in our north temperate forest (Canada), subtropical forest (Argentina), and tropical forest (Ecuador) study areas, where 12-17 excavator species produce cavities that partially overlap in size, and in some cases are used interchangeably by nonexcavators, likely increasing the resilience of the nest web (Cockle et al. 2011, 2019b, Cockle and Martin 2015, Van der Hoek and Martin 2018).

Nest web heterogeneity occurs at multiple levels. At the smallest level, wood hardness and decay organisms are distributed heterogeneously within individual trees, determining where and when birds can excavate a cavity (Larrieu et al. 2014). At the nest web community level, a few tree species represent key network hubs, with $<20 \%$ of tree species accounting for $>50 \%$ of nests, and $<50 \%$ of tree species accounting for $>90 \%$ of nests (Fig. 4 ), a nonlinear, approximately scale-free pattern common to many complex systems (Parrott and Meyer 2012). At the landscape level, nest webs can exhibit high values of beta diversity, as cavity abundance and nest web composition vary with elevation and disturbance history (Fig. 4A; Politi et al. 2012, Ibarra et al. 2017b, Van der Hoek and Martin 2018), influencing nest web structure and function (Robles and Martin 2014). Across regions, we find heterogeneity in the components, diversity, and structure of nest webs. Whereas nest webs in North America exhibit low interaction evenness, depending primarily on cavities created by excavators in standing trees of one or two species (Martin et al. 2004, Blanc and Walters 2008b, Cooke and Hannon 2011), those in tropical, subtropical, and temperate forests of South America exhibit higher interaction evenness and involve a more diverse array of

Fig. 4. Across multiple nest webs, interactions are disproportionately distributed, with $<20 \%$ of tree species accounting for $>50 \%$ of nests (dashed vertical line), and $<50 \%$ of tree species accounting for $>90 \%$ of nests (solid vertical line). Data sources: Ruggera et al. (2016); T. A. Altamirano and J. T. Ibarra (unpublished data), K. L. Cockle (unpublished data), K. Martin (unpublished data).

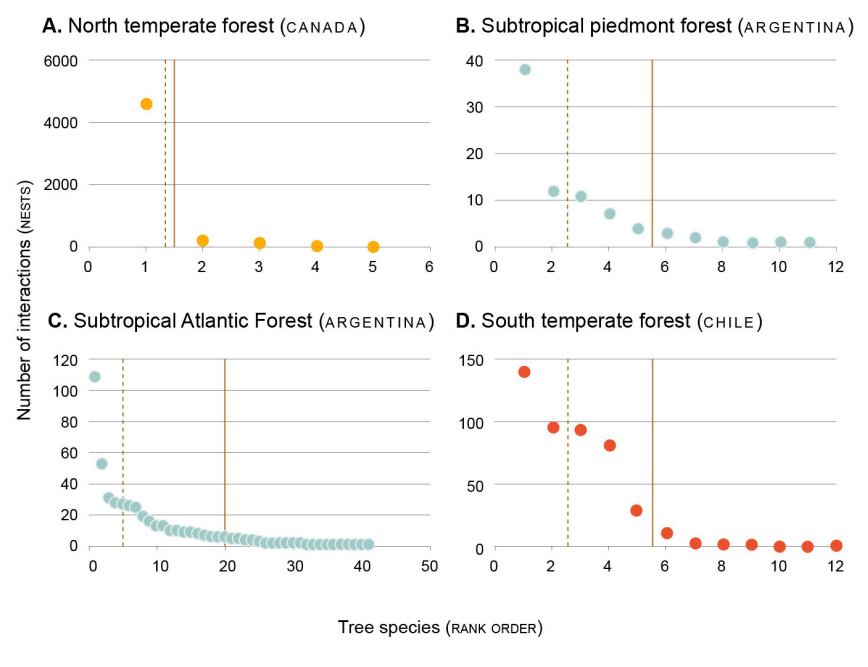


cavity substrates, including many tree species, palms, bamboo, tree ferns, arboreal termite nests, and fallen trees (Cockle et al. 2012, 2019b, Altamirano et al. 2017, Van der Hoek and Martin 2018). Logging can result in disproportionate biodiversity losses especially when key hubs (tree species or sizes) are targeted; however, high redundancy of species or functions likely increases resilience of the nest web (Cockle et al. 2010, Ruggera et al. 2016, Ibarra et al. 2017a).

\section{Memory}

The past conditions of a tree, forest, landscape, or regional biome, including historical land use practices, will have a legacy effect on the types of cavities that are produced, how long they last, and how species interact around this resource (Fig. 5B, C). Large decaying and standing dead trees retain the memory of past forest conditions in their wood properties and canopy structure (Briffa 2000), and are most likely to generate cavities for a range of vertebrate fauna (Blanc and Martin 2012). In many systems, cavities in living trees may persist for several decades (Lindenmayer and Wood 2010, Wesołowski 2012, Cockle et al. 2017; Fig. 5C), during which they can be used $>20$ times by nesting vertebrates (Cockle et al. 2019a).

Fig. 5. Properties of nest webs for different study systems in the Americas. (A) Heterogeneity (Chile): stands with a dense understory, large-decaying trees, and a deep leaf-litter create microhabitats (structural complexity) not only for cavity nesters, but also for insects and small mammals, the main food items for several cavity nesters (Caviedes and Ibarra 2017; J. T. Ibarra, unpublished data). (B) Memory (Ecuador): agroforests sustain habitat legacies (standing dead trees) that are highly used by excavators. They have a disproportionate impact on cavity-nesting community composition (Y. Van der Hoek, unpublished data). (C) Memory (Argentina): tree-cavity persistence increases with tree size, so that large old-growth trees have a longer legacy (Cockle et al. 2017). (D) Uncertainty (Canada): woodpecker (WP) populations increased during and after an insect outbreak (grey area). Nonexcavators switched from Northern Flicker (Colaptes auratus) cavities to cavities created by a broader suite of woodpeckers, leading to changes in nest web architecture, including increased evenness (Cockle and Martin 2015).
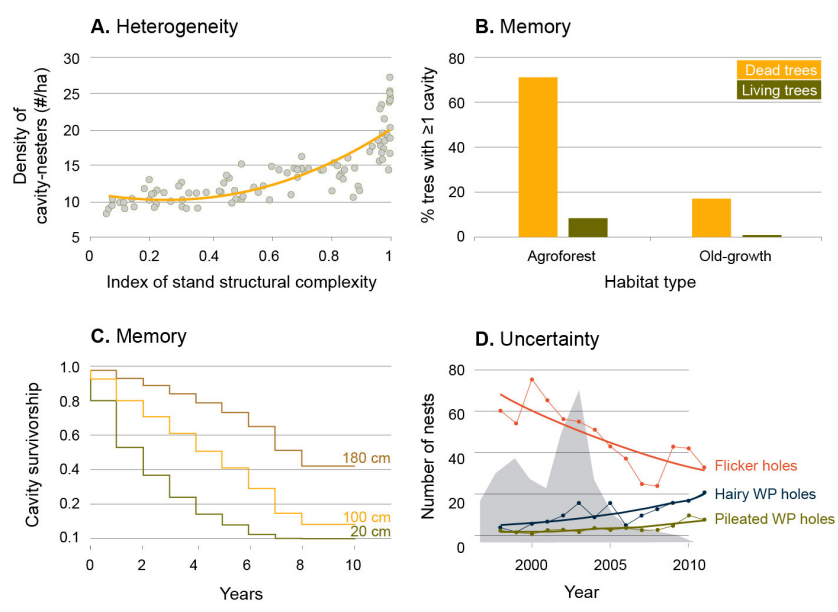

Although cavities are hosted by individual trees, the memory processes of these individuals are derived from interaction networks with other organisms at larger scales. For example, forest patches surrounding a recently disturbed area will supply sources of memory, often vectored by mobile linkages, e.g., seed and spore-dispersing animals, that speed up regeneration (Filotas et al. 2014). A single fire event can influence habitat legacies for one or several centuries, for example, by destroying all existing cavities, by dramatically altering stand structure and composition, or by creating high densities of standing dead trees (Dansereau and Bergeron 1993, Lindenmayer et al. 2012). In Chile, standing dead trees increase forest-stand structural complexity (Caviedes and Ibarra 2017) and positively influence breeding site selection and fecundity of cavity nesters (Altamirano et al. 2017; Fig. 4B). Currently, legacy trees from previous centuries sustain cavitynesting communities in many secondary forests, partially logged forests, and agricultural landscapes, where cavity-using vertebrates would not otherwise be able to persist (Fischer et al. 2010, Lindenmayer et al. 2014, Ibarra et al. 2017a).

\section{Uncertainty and nonlinearity}

Nest webs can be a useful tool for predicting the effects of disturbance on avian community structure (Blanc and Walters 2007), but their spatio-temporal dynamics are also riddled with uncertainty. Biotic, e.g., insect outbreaks, abiotic, e.g., fires or volcanic eruptions, and anthropogenic, e.g., logging or humaninduced fires, forces can modify the structural and functional attributes of nest web systems in unforeseen ways (Filotas et al. 2014, Ruggera et al. 2016), resulting in shifts in nest web architecture and nonlinear responses to disturbance. For example, where selective logging removed half the basal area of trees from subtropical forests in Argentina, the cavity-nesting community responded nonlinearly with nine times fewer cavities and 17 times fewer nests in logged areas than in old-growth forests (Cockle et al. 2010).

Sources of uncertainty in the system not only reduce our ability to predict the future state of nest webs, they also generate variability that may be amplified by feedback loops, leading to the emergence of novel relations or links among species. When nest webs in western Canada experienced an outbreak of mountain pine beetle, the keystone species in the excavator guild changed from Northern Flickers (Colaptes auratus) before the outbreak, to a broader suite of less common woodpeckers, increasing network evenness and decreasing nestedness (Cockle and Martin 2015; Fig. 4D). Then, fires destroyed many cavities, and flickers increased their excavation rate by more than $30 \%$ (Wiebe 2014, 2017), suggesting that flickers (and other abundant excavators) may play a key role in regulating cavity supply. Research on the long-term dynamics of nest web systems at multiple levels would help reduce uncertainty about their responses to social-ecological disturbances.

\section{CONCLUSION: NURTURING RESILIENT NEST WEBS}

Linkages among nest web entities (individuals, species, guilds), functioning of interacting adaptive cycles, i.e., panarchy, and properties resulting from their interactions, are key factors contributing to the resilience of forest communities. Heterogeneity, redundancy, and memory allow nest web systems to absorb some degree of disturbance without undergoing a regime shift, that is, without changing the basic structures and functions, and thus the identity, of nest webs. 
We recommend that forest and wildlife ecologists, managers, and public agencies charged with forest biodiversity conservation attempt to define thresholds at which nest web systems are no longer considered resilient, i.e., basic structures and functionssystem's identity - are altered (Holling 1973, Walker and Salt 2006). Although quantifiable, thresholds are frequently set according to human values (Messier et al. 2013, Biggs et al. 2015), and vary depending on the adaptive cycle under consideration for management intervention. We suggest that a future research agenda on nest webs should include an assessment of thresholds and should explicitly contemplate human institutions shaping nest web systems, so that the panarchy can be understood as a coupled social-ecological system (Holling 2001). A socialecological research agenda will allow better and more realistic assessments of how nest web dynamics and possible futures are shaped by the pressure from multiple stakeholders and policy makers acting at local, national, and international scales (Filotas et al. 2014). This applied research agenda will also enable increasingly sophisticated forest management that attends several adaptive cycles, at the individual tree or community levels, and also above to the landscape and regional levels.

Studying and managing forests to sustain nest web resilience will require attention to the full panarchy of the adaptive cycles. For example, a study using a panarchy framework on reindeer (Rangifer tarandus) husbandry shows the incongruence between forest management across different levels: the management scale of a large forest company is that of their land holdings within a region (varying from $<10$ ha to a few hundred ha) while, on the other hand, the management scale of one reindeer herding district involves the landscape used by a winter herding group during a decade or more (several tens of thousands of ha; Moen and Keskitalo 2010). In this case, it is critical to embrace a multilevel perspective from the lichen (feeding) resource to a rotational use of grazing lands in relation to the dynamics of the animals and variations in weather, to increase their buffering capacity that maintains resilience in their resource use (Sandström et al. 2006).

In a nest web context, it is critical to maximize memory focusing on what is retained, what is removed (Gustafsson et al. 2012, Mori and Kitagawa 2014, Baker et al. 2015), and what can be developed through forestry practices in adaptive cycles, from individual trees to regions. We need to find locally acceptable ways to retain and recruit large trees, ensure a variety of tree densities and species compositions in the landscape, and manage regional land-use and disturbance regimes to ensure a representative mosaic of forests (Lindenmayer and Laurance 2017, Koch and Munks 2018). In our study area in subtropical forests of Argentina, the national "Ley de Bosques Nativos" (Law 26331) and associated territorial planning under Provincial Law XVI No 105 were followed by reduced annual deforestation rates at the provincial level $(30,000$ $\mathrm{km}^{2}$ ). However, these laws are insufficient, alone, to conserve representative cavity-nesting communities because selective logging of stands on unsustainable cycles ( $<20$ years) leaves impoverished forests where timber is not worth harvesting legally, and large degraded forest properties are slowly abandoned to illegal logging and unregulated deforestation for small-scale tobacco farming (Manzanal and Arzeno 2011, Campanello et al. 2019). To conserve a representative diversity of nest webs, finer scale policies are needed to address critical social-ecological concerns at the scale of individual forestry operations and small farming properties (20-100 ha) that dominate under-represented cavity-nesting assemblages, such as those of Araucaria forests (Cockle et al. 2019b).

Specific management needs will vary across nest web systems. A great challenge for managing to nurture resilience in socialecological systems, in this case nest webs in forests, is that the governance of different countries and regions face different sources of uncertainty and historical and contemporary issues, e.g., political and socioeconomic (Messier et al. 2013). We must thus understand both the internal dynamics within each country and region, and the interactions among stakeholders to assess and hopefully nurture the resilience of the system as a whole. In subtropical Argentina and south temperate Chile, specifically, we suggest it is critical to rethink current forest policies (or the lack of them) that simultaneously (1) promote large monoculture tree plantations, and (2) degrade native forest through unsustainable ("high-grade") logging operations that overwhelmingly remove the largest living trees with greatest value to biodiversity (Cockle et al. 2012, 2015, Ibarra et al. 2017a). At the same time, forest and farm management could take advantage of nest web resilience by ensuring that nonexcavators have opportunities to switch to the relatively ephemeral woodpecker cavities in smaller and fastgrowing trees, and ensuring that the landscape is sufficiently heterogeneous and redundant to provide foraging and nesting resources year round. For example, at our study area in Canada, nonexcavators most often use cavities excavated by woodpeckers in trembling aspen (95\%; Martin et al. 2004, Cockle et al. 2011). Logging operations in this region retain most aspen and large Douglas fir (Pseudotsuga menziesii), reducing tree density but conserving the key habitat structures for cavity-using vertebrates, i.e., retaining nest web memory. The nest web is resilient to these practices, but current shifts toward clear-cutting, herbicide spraying, and planting monocultures in the lower elevation Douglas fir forest could rapidly undermine this resilience.

Managing disturbance regimes and protecting the shifting mosaic of different ages and composition of forests in the landscape, as well as mitigating climate shifts and attending to colonization of species at the biome level, will ensure a much more robust system of forest biodiversity than is possible with the historic management focus at the tree and forest community levels. Acknowledging the complexity, both ecological and social, of nest web systems may also help researchers and forest managers effectively communicate their management recommendations to the public (Parrott and Meyer 2012). Management and policies at all levels should aim to nurture resilience in relation to long-term adaptive conservation objectives in an uncertain future.

Responses to this article can be read online at: http://www.ecologyandsociety.org/issues/responses. php/11590

\section{Acknowledgments:}

This study was funded by CONICYT/FONDECYT de Inicio (11160932), “NETBIOAMERICAS” CONICYT/Apoyo a la Formación de Redes Internacionales entre Centros de Investigación (REDES150047), CONICYT/FONDAP/15110006 and ANID 
PIA/BASAL FB0002. We also received support from the Center for the Socioeconomic Impact of Environmental Policies (CESIEP,) which is a Millennium Nucleus supported by the Millennium Scientific Initiative of the Chilean Ministry of Economy, Development and Tourism. Kristina Hick provided comments that helped improve a prior version of this article. We acknowledge the help from Daniela Barrera and Leyla Musleh preparing the figures.

\section{Data Availability Statement:}

This does not apply to our synthesis paper

\section{LITERATURE CITED}

Alfaro, R., E. Campbell, and B. Hawkes. 2010. Historical frequency, intensity and extent of mountain pine beetle disturbance in British Columbia. Mountain Pine Beetle working paper 2009-30. Natural Resources Canada, Canadian Forest Service, Victoria, British Columbia, Canada. [online] URL: https://www. for.gov.bc.ca/HFD/library/Documents/bib109167.pdf

Altamirano, T. A., J. T. Ibarra, K. Martin, and C. Bonacic. 2017. The conservation value of tree decay processes as a key driver structuring tree cavity nest webs in South American temperate rainforests. Biodiversity and Conservation 26(10):2453-2472. https://doi.org/10.1007/s10531-017-1369-x

Armesto, J. J., D. Manuschevich, A. Mora, C. Smith-Ramirez, R. Rozzi, A. M. Abarzúa, and P. A. Marquet. 2010. From the Holocene to the Anthropocene: a historical framework for land cover change in southwestern South America in the past 15,000 years. Land Use Policy 27(2):148-160. https://doi.org/10.1016/j. landusepol.2009.07.006

Bai, M.-L., F. Wichmann, and M. Mühlenberg. 2003. The abundance of tree holes and their utilization by hole-nesting birds in a primeval boreal forest of Mongolia. Acta Ornithologica 38 (2):95-102. https://doi.org/10.3161/068.038.0205

Baker, S. C., C. B. Halpern, T. J. Wardlaw, R. L. Crawford, R. E. Bigley, G. J. Edgar, S. A. Evans, J. F. Franklin, G. J. Jordan, Y. Karpievitch, T. A. Spies, and R. J. Thomson. 2015. Short- and long-term benefits for forest biodiversity of retaining unlogged patches in harvested areas. Forest Ecology and Management 353:187-195. https://doi.org/10.1016/j.foreco.2015.05.021

Barreau, A., J. T. Ibarra, F. S. Wyndham, A. Rojas, and R. A. Kozak. 2016. How can we teach our children if we cannot access the forest? Generational change in Mapuche knowledge of wild edible plants in Andean temperate ecosystems of Chile. Journal of Ethnobiology 36(2):412-432. https://doi.org/10.2993/0278-07$\underline{71-36.2 .412}$

Biggs, R., M. Schlüter, and M. L. Schoon. 2015. Principles for building resilience: sustaining ecosystem services in socialecological systems. Cambridge University Press, Cambridge, UK. https://doi.org/10.1017/CBO9781316014240

Blanc, L. A., and K. Martin. 2012. Identifying suitable woodpecker nest trees using decay selection profiles in trembling aspen (Populus tremuloides). Forest Ecology and Management 286:192-202. https://doi.org/10.1016/j.foreco.2012.08.021
Blanc, L. A., and J. R. Walters. 2007. Cavity-nesting community webs as predictive tools: where do we go from here? Journal of Ornithology 148(2):417-423. https://doi.org/10.1007/s10336-007-0232-3

Blanc, L. A., and J. R. Walters. 2008a. Cavity excavation and enlargement as mechanisms for indirect interactions in an avian community. Ecology 89(2):506-514. https://doi.org/10.1890/07-0219.1

Blanc, L. A., and J. R. Walters. 2008b. Cavity-nest webs in a longleaf pine ecosystem. Condor 110(1):80-92. https://doi. org/10.1525/cond.2008.110.1.80

Briffa, K. R. 2000. Annual climate variability in the Holocene: interpreting the message of ancient trees. Quaternary Science Reviews 19:87-105. https://doi.org/10.1016/S0277-3791(99)00056-6

Bunnell, F. L., and G. B. Dunsworth. 2009. Forestry and biodiversity: learning how to sustain biodiversity in managed forests. UBC Press, Vancouver, British Columbia, Canada.

Campanello, P. I., J. Von Below, N. I. Hilgert, K. L. Cockle, M. Villagra, D. di Francescantonio, D. S. García, M. Jaramillo, O. A. Gauto, and G. Goldstein. 2019. ¿Es posible el uso sostenible del bosque en Misiones? Necesidades de manejo a diferentes escalas, investigación, intervenciones de alto impacto y más recursos económicos. Ecología Austral 29:122-137. https://doi. org/10.25260/EA.19.29.1.0.756

Caviedes, J., and J. T. Ibarra. 2017. Influence of anthropogenic disturbances on stand structural complexity in Andean temperate forests: implications for managing key habitat for biodiversity. PLoS ONE 12(1):e0169450. https://doi.org/10.1371/journal. pone. 0169450

Cockle, K. L., A. Bodrati, M. Lammertink, and K. Martin. 2015. Cavity characteristics, but not habitat, influence nest survival of cavity-nesting birds along a gradient of human impact in the subtropical Atlantic Forest. Biological Conservation 184:193-200. https://doi.org/10.1016/j.biocon.2015.01.026

Cockle, K. L., J. T. Ibarra, T. A. Altamirano, and K. Martin. 2019b. Interspecific networks of cavity-nesting vertebrates reveal a critical role of broadleaf trees in endangered Araucaria mixed forests of South America. Biodiversity and Conservation 28:3371-3386. https://doi.org/10.1007/s10531-019-01826-4

Cockle, K. L., and K. Martin. 2015. Temporal dynamics of a commensal network of cavity-nesting vertebrates: increased diversity during an insect outbreak. Ecology 96(4):1093-1104. https://doi.org/10.1890/14-1256.1

Cockle, K. L., K. Martin, and A. Bodrati. 2017. Persistence and loss of tree cavities used by birds in the subtropical Atlantic Forest. Forest Ecology and Management 384:200-207. https://doi. org/10.1016/j.foreco.2016.10.052

Cockle, K. L., K. Martin, and M. C. Drever. 2010. Supply of treeholes limits nest density of cavity-nesting birds in primary and logged subtropical Atlantic forest. Biological Conservation 143 (11):2851-2857. https://doi.org/10.1016/j.biocon.2010.08.002

Cockle, K. L., K. Martin, and G. Robledo. 2012. Linking fungi, trees, and hole-using birds in a Neotropical tree-cavity network: pathways of cavity production and implications for conservation. Forest Ecology and Management 264:210-219. https://doi. org/10.1016/j.foreco.2011.10.015 
Cockle, K. L., K. Martin, and T. Wesołowski. 2011. Woodpeckers, decay, and the future of cavity-nesting vertebrate communities worldwide. Frontiers in Ecology and the Environment 9(7):377-382. https://doi.org/10.1890/110013

Cockle, K. L., M. K. Trzcinski, K. L. Wiebe, A. B. Edworthy, and K. Martin. 2019a. Lifetime productivity of tree cavities used by cavity-nesting animals in temperate and subtropical forests. Ecological Applications 29(5):e01916. https://doi.org/10.1002/ eap. 1916

Cooke, H. A., and S. J. Hannon. 2011. Do aggregated harvests with structural retention conserve the cavity web of old upland forest in the boreal plains? Forest Ecology and Management 261 (3):662-674. https://doi.org/10.1016/j.foreco.2010.11.023

Dansereau, P.-R., and Y. Bergeron. 1993. Fire history in the southern boreal forest of northwestern Quebec. Canadian Journal of Forest Research 23:25-32. https://doi.org/10.1139/x93-005

Dantas Oliveira, C. 2015. O efeito da idade da floresta na disponibilidade de cavidades para aves não escavadoras nas reservas do Projeto Dinâmicas Biológicas de Fragmentos Florestais (PDBFF), Amazônia Central. Universidade Federal Do Amazonas (UFAM), Instituto de Ciencias Biológicas (ICB), Manaus, Brasil.

DeGraaf, R. M., and A. L. Shigo. 1985. Managing cavity trees for wildlife in the northeast. General Technical Report NE-101. U. S. Forest Service, Northeastern Forest Experimental Station, Durham, New Hampshire, USA.

Drever, M. C., and K. Martin. 2007. Spending time in the forest: responses of cavity-nesters to temporal changes in forest health in interior British Columbia. Pages 236-251 in J. A. Bissonette and I. Stroch, editors. Temporal dimensions of landscape ecology: wildlife responses to variable resources. Springer, New York, New York, USA. https://doi.org/10.1007/978-0-387-45447-4 14

Dueñas, J. F., C. Jarrett, I. Cummins, and E. Logan-Hines. 2016. Amazonian Guayusa (Ilex guayusa Loes.): a historical and ethnobotanical overview. Economic Botany 70(1):85-91. https:// doi.org/10.1007/s12231-016-9334-2

Echeverría, C., A. Newton, L. Nahuelhual, D. Coomes, and J. M. Rey-Benayas. 2012. How landscapes change: integration of spatial patterns and human processes in temperate landscapes of southern Chile. Applied Geography 32(2):822-831. https://doi. org/10.1016/j.apgeog.2011.08.014

Edworthy, A. B., M. C. Drever, and K. Martin. 2011. Woodpeckers increase in abundance but maintain fecundity in response to an outbreak of mountain pine bark beetles. Forest Ecology and Management 261:203-210. https://doi.org/10.1016/j. foreco.2010.10.006

Edworthy, A. B., and K. Martin. 2014. Long-term dynamics of the characteristics of tree cavities used for nesting by vertebrates. Forest Ecology and Management 334:122-128. https://doi. org/10.1016/j.foreco.2014.09.001

Edworthy, A. B., M. K. Trzcinski, K. L. Cockle, K. L. Wiebe, and K. Martin. 2017. Tree cavity occupancy by nesting vertebrates across cavity age. Journal of Wildlife Management 82(3):639-648. https://doi.org/10.1002/jwmg.21398
Filotas, E., L. Parrott, P. J. Burton, R. L. Chazdon, K. D. Coates, L. Coll, S. Haeussler, K. Martin, S. Nocentini, K. J. Puettmann, F. E. Putz, S. W. Simard, and C. Messier. 2014. Viewing forests through the lens of complex systems science. Ecosphere 5(1):1-23. https://doi.org/10.1890/ES13-00182.1

Fischer, J., J. Stott, and B. S. Law. 2010. The disproportionate value of scattered trees. Biological Conservation 143 (6):1564-1567. https://doi.org/10.1016/j.biocon.2010.03.030

Floyd, C., and K. Martin. 2016. Avian ecosystem engineers: birds that excavate cavities. Pages 296-318 in C. H. Skekercioglu, D. G. Wenny, and C. J. Whelan, editors. Why birds matter. University of Chicago Press, Chicago, Illinois, USA.

Franklin, J. F., and R. Van Pelt. 2004. Spatial aspects of structural complexity in old-growth forests. Journal of Forestry 102:22-28.

Gunderson, L. H., and C. S. Holling. 2002. Panarchy: understanding transformations in human and natural systems. Island Press, Washington, D.C., USA.

Gustafsson, L., S. C. Baker, J. Bauhus, W. J. Beese, A. Brodie, J. Kouki, D. B. Lindenmayer, A. Löhmus, G. Martínez Pastur, C. Messier, M. Neyland, B. Palik, A. Sverdrup-Thygeson, W. J. A. Volney, A. Wayne, and J. F. Franklin. 2012. Retention forestry to maintain multifunctional forests: a world perspective. BioScience 62(7):633-645. https://doi.org/10.1525/bio.2012.62.7.6

Harley, C. D. G. 2011. Climate change, keystone predation, and biodiversity loss. Science 334(6059):1124-1127. https://doi. org/10.1126/science.1210199

Holbrook, K. M., and B. A. Loiselle. 2009. Dispersal in a Neotropical tree Virola flexuosa (Myristicaceae): does hunting of large vertebrates limit seed removal? Ecology 90(6):1449-1455. https://doi.org/10.1890/08-1332.1

Holling, C. S. 1973. Resilience and stability of ecological systems. Annual Review of Ecology and Systematics (4):1-23. https://doi. org/10.1146/annurev.es.04.110173.000245

Holling, C. S. 2001. Understanding the complexity of economic, ecological, and social systems. Ecosystems 4:390-405. https://doi. org/10.1007/s10021-001-0101-5

Hutto, R. L. 2006. Toward meaningful snag-management guidelines for postfire salvage logging in North American conifer forests. Conservation Biology 20(4):984-993. https://doi. org/10.1111/j.1523-1739.2006.00494.x

Ibarra, J. T., N. Gálvez, T. A. Altamirano, J. Caviedes, I. M. Rojas, C. Bonacic, and K. Martin. 2017b. Seasonal dynamics of avian guilds inside and outside core protected areas in an Andean Biosphere Reserve of southern Chile. Bird Study 64(3):410-420. https://doi.org/10.1080/00063657.2017.1368447

Ibarra, J. T., and K. Martin. 2015. Biotic homogenization: loss of avian functional richness and habitat specialists in disturbed Andean temperate forests. Biological Conservation 192:418-427. https://doi.org/10.1016/j.biocon.2015.11.008

Ibarra, J. T., M. Martin, K. L. Cockle, and K. Martin. 2017a. Maintaining ecosystem resilience: functional responses of tree cavity nesters to logging in temperate forests of the Americas. Scientific Reports 7:4467. https://doi.org/10.1038/s41598-017-04733-2 
Jusino, M. A., D. L. Lindner, M. T. Banik, K. R. Rose, and J. R. Walters. 2016. Experimental evidence of a symbiosis between Red-cockaded Woodpeckers and fungi. Proceedings of the Royal Society B: Biological Sciences 283(1827):20160106. https://doi. org/10.1098/rspb.2016.0106

Koch, A., and S. Munks. 2018. A proposed strategy for maintaining mature forest habitat in Tasmania's wood production forests. Ecological Management \& Restoration 19(3):239-246. https://doi.org/10.1111/emr.12337

Koch, A. J., S. A. Munks, D. Driscoll, and J. B. Kirkpatrick. 2008. Does hollow occurrence vary with forest type? A case study in wet and dry Eucalyptus obliqua forest. Forest Ecology and Management 255:3938-3951. https://doi.org/10.1016/i.foreco.2008.03.025

Lammertink, M., J. M. Fernández, and K. L. Cockle. 2019. Helmeted Woodpeckers roost in decay-formed cavities in large living trees: a clue to an old-growth forest association. Condor 121 (1):duy016. https://doi.org/10.1093/condor/duy016

Larrieu, L., A. Cabanettes, P. Gonin, T. Lachat, Y. Paillet, S. Winter, C. Bouget, and M. Deconchat. 2014. Deadwood and tree microhabitat dynamics in unharvested temperate mountain mixed forests: a life-cycle approach to biodiversity monitoring. Forest Ecology and Management 334:163-173. https://doi. org/10.1016/j.foreco.2014.09.007

Levin, S. A. 1998. Ecosystems and the biosphere as complex adaptive systems. Ecosystems 1:431-436. https://doi.org/10.1007/ $\underline{\mathrm{s} 100219900037}$

Lindenmayer, D. B., R. B. Cunningham, C. F. Donnelly, and M. T. Tanton. 1993. The abundance and development of cavities in Eucalyptus trees: a case study in the montane forests of Victoria, southeastern Australia. Forest Ecology and Management 60:77-104. https://doi.org/10.1016/0378-1127(93)90024-H

Lindenmayer, D. B., and W. F. Laurance. 2017. The ecology, distribution, conservation and management of large old trees. Biological Reviews 92(3):1434-1458. https://doi.org/10.1111/ $\underline{\text { brv. } 12290}$

Lindenmayer, D. B., W. F. Laurance, and J. F. Franklin. 2012. Global decline in large old trees. Science 338:1305-1306. https:// doi.org/10.1126/science. 1231070

Lindenmayer, D. B., W. F. Laurance, J. F. Franklin, G. E. Likens, S. C. Banks, W. Blanchard, P. Gibbons, K. Ikin, D. Blair, L. McBurney, A. D. Manning, and J. A. R. Stein. 2014. New policies for old trees: averting a global crisis in a keystone ecological structure. Conservation Letters 7(1):61-69. https://doi.org/10.1111/ $\underline{\text { conl.12013 }}$

Lindenmayer, D. B., and J. T. Wood. 2010. Long-term patterns in the decay, collapse, and abundance of trees with hollows in the mountain ash (Eucalyptus regnans) forests of Victoria, southeastern Australia. Canadian Journal of Forest Research 40 (1):48-54. https://doi.org/10.1139/X09-185

Lonsdale, D., M. Pautasso, and O. Holdenrieder. 2008. Wooddecaying fungi in the forest: conservation needs and management options. European Journal of Forest Research 127:1-22. https:// doi.org/10.1007/s10342-007-0182-6
Manikandan, P., and P. Balasubramanian. 2018. Sequential use of tree cavities by birds and nest web in a riparian forest in Southwest India. Acta Ornithologica 53(1):49-60. https://doi. org/10.3161/00016454AO2018.53.1.005

Manzanal, M., and M. Arzeno 2011. Territorio y poder en la globalización. Disputas por la tierra en el nordeste de Misiones, Argentina. Revista Paraguaya de Sociología 138:163-191.

Martin, K., K. E. H. Aitken, and K. L. Wiebe. 2004. Nest sites and nest webs for cavity-nesting communities in interior British Columbia, Canada: nest characteristics and niche partitioning. Condor 106(1):5-19. https://doi.org/10.1093/condor/106.1.5

Martin, K., and J. M. Eadie. 1999. Nest webs: a community-wide approach to the management and conservation of cavity-nesting forest birds. Forest Ecology and Management 115:243-257. https:// doi.org/10.1016/S0378-1127(98)00403-4

Martin, K., A. Norris, and M. Drever. 2006. Effects of bark beetle outbreaks on avian biodiversity in the British Columbia interior: implications for critical habitat management. BC Journal of Ecosystems and Management 7(3):10-24.

Messier, C., and K. J. Puettmann. 2011. Forests as complex adaptive systems: implications for forest management and modelling. Italian Journal of Forest and Mountain Environments 66(3):249-258.

Messier, C., K. J. Puettmann, and K. D. Coates. 2013. Managing forests as complex adaptive systems: building resilience to the challenge of global change. Routledge, New York, New York, USA. https://doi.org/10.4324/9780203122808

Moen, J., and E. C. H. Keskitalo. 2010. Interlocking panarchies in multi-use boreal forests in Sweden. Ecology and Society 15 (3):17. https://doi.org/10.5751/ES-03444-150317

Mori, A. S., and R. Kitagawa. 2014. Retention forestry as a major paradigm for safeguarding forest biodiversity in productive landscapes: a global meta-analysis. Biological Conservation 175:65-73. https://doi.org/10.1016/j.biocon.2014.04.016

Norris, A. R., and K. Martin. 2014. Direct and indirect effects of an insect outbreak increase the reproductive output for an avian insectivore and nest-cavity excavator, the Red-breasted Nuthatch Sitta canadensis. Journal of Avian Biology 45(3):280-290. https:// doi.org/10.1111/jav.00112

Pakkala, T., J. Tiainen, and J. Kouki. 2017. The importance of nesting cavity and tree reuse in the Three-toed Woodpecker Picoides tridactylus in dynamic forest landscapes. Annales Zoologici Fennici 54:175-191. https://doi.org/10.5735/086.054.0116

Parrott, L., and W. S. Meyer. 2012. Future landscapes: managing within complexity. Frontiers in Ecology and the Environment 10:382-389. https://doi.org/10.1890/110082

Perry, D. A., P. F. Hessburg, C. N. Skinner, T. A. Spies, S. L. Stephens, A. H. Taylor, J. F. Franklin, B. McComb, and G. Riegel. 2011. The ecology of mixed severity fire regimes in Washington, Oregon, and Northern California. Forest Ecology and Management 262(5):703-717. https://doi.org/10.1016/j.foreco.2011.05.004

Perz, S. G., C. Aramburú, and J. Bremner. 2005. Population, land use and deforestation in the Pan Amazon Basin: a comparison of 
Brazil, Bolivia, Colombia, Ecuador, Perú and Venezuela. Environment, Development and Sustainability 7:23-49. https://doi. org/10.1007/s10668-003-6977-9

Politi, N., M. Hunter, and L. Rivera. 2012. Assessing the effects of selective logging on birds in Neotropical piedmont and cloud montane forests. Biodiversity and Conservation 21:3131-3155. https://doi.org/10.1007/s10531-012-0358-3

Puettmann, K. J., K. D. Coates, and C. Messier. 2009. A critique of silviculture: managing for complexity. Island Press, Washington, D.C., USA.

Rau, M. F. 2005. Land use change and natural Araucaria forest degradation: northeastern Misiones - Argentina. Dissertation. Albert-Ludwigs-University, Freiburg in Breisgau, Germany.

Renton, K. 2001. Lilac-crowned Parrot diet and food resource availability: resource tracking by a parrot seed predator. Condor 103(1):62-69. https://doi.org/10.1093/condor/103.1.62

Ríos, R. C. 2006. Caracterização florística e fitosociológica da vegetação arbórea em três unidades pedológicas do Parque Provincial Cruce Caballero, Misiones, Argentina. Mestre em Ciências Florestais, Universidade Federal do Paraná, Curitiba, Brazil.

Robles, H., and K. Martin. 2014. Habitat-mediated variation in the importance of ecosystem engineers for secondary cavity nesters in a nest web. PLOS ONE 9(2):e90071. https://doi. org/10.1371/journal.pone.0090071

Ruggera, R. A., A. A. Schaaf, C. G. Vivanco, N. Politi, and L. O. Rivera. 2016. Exploring nest webs in more detail to improve forest management. Forest Ecology and Management 372:93-100. https://doi.org/10.1016/j.foreco.2016.04.010

Sandström, C., J. Moen, C. Widmark, and Ö. Danell. 2006. Progressing toward co-management through collaborative learning: forestry and reindeer husbandry in dialogue. International Journal of Biodiversity Science and Management 2:326-333. https://doi.org/10.1080/17451590609618153

Simard, S., K. Martin, A. Vyse, and L. Bruce. 2013. Metanetworks of fungi, fauna and flora as agents of complex adaptive systems. Pages 133-164 in C. Messier, K. J. Puettmann, and K. D. Coates, editors. Managing forests as complex adaptive systems: building resilience to the challenge of global change. Routledge, New York, New York, USA. https://doi.org/10.4324/9780203122808

Speziale, K. L., S. A. Lambertucci, G. Gleiser, J. L. Tella, F. Hiraldo, and M. A. Aizen. 2018. An overlooked plant-parakeet mutualism counteracts human overharvesting on an endangered tree. Royal Society Open Science 5(1):171456. https://doi. org/10.1098/rsos. 171456

Strogatz, S. H. 2001. Exploring complex networks. Nature 410:268-276. https://doi.org/10.1038/35065725

Tabarelli, M., W. Mantovani, and C. A. Peres. 1999. Effects of habitat fragmentation on plant guild structure in the montane Atlantic forest of southeastern Brazil. Biological Conservation 91 (2):119-127. https://doi.org/10.1016/S0006-3207(99)00085-3

Tella, J. L., F. V. Dénes, V. Zulian, N. P. Prestes, J. Martínez, G. Blanco, and F. Hiraldo. 2016. Endangered plant-parrot mutualisms: seed tolerance to predation makes parrots pervasive dispersers of the Parana pine. Scientific Reports 6:31709. https:// doi.org/10.1038/srep31709

Torres, B., O. J. Maza, P. Aguirre, L. Hinojosa, and S. Günter. 2015. The contribution of traditional agroforestry to climate change adaptation in the Ecuadorian Amazon: the chakra system. Pages 1973-1994 in W. Leal Filho, editor. Handbook of climate change adaptation. Springer, Berlin, Germany. https://doi. org/10.1007/978-3-642-38670-1 102

Van der Hoek, Y., G. V Gaona, and K. Martin. 2017. The diversity, distribution and conservation status of the tree-cavitynesting birds of the world. Diversity and Distributions 23:1120-1131. https://doi.org/10.1111/ddi.12601

Van der Hoek, Y., and K. Martin. 2018. Woodpecker cavity-tree selection in the Ecuadorean Amazon Region. Ornitologia Neotropical 29:95-99.

Walker, B. H. 1992. Biodiversity and ecological redundancy. Conservation Biology 6(1):18-23. https://doi.org/10.1046/ j.1523-1739.1992.610018.X

Walker, B., and D. Salt. 2006. Resilience thinking: sustaining ecosystems and people in a changing world. Island Press, Washington, D.C., USA.

Wesołowski, T. 2012. "Lifespan" of non-excavated holes in a primeval temperate forest: a 30 year study. Biological Conservation 153:118-126. https://doi.org/10.1016/j.biocon.2012.04.017

Wesołowski, T. 2017. Failed predator attacks: a direct test of security of tree cavities used by nesting Marsh Tits (Poecile palustris). Auk 134(4):802-810. https://doi.org/10.1642/auk-17-51.1

Wesołowski, T., and P. Rowiński. 2004. Breeding behaviour of Nuthatch Sitta europaea in relation to natural hole attributes in a primeval forest. Bird Study 51(2):143-155. https://doi. org/10.1080/00063650409461346

Wiebe, K. L. 2014. Responses of cavity-nesting birds to fire: testing a general model with data from the Northern Flicker. Ecology 95(9):2537-2547. https://doi.org/10.1890/13-1711.1

Wiebe, K. L. 2017. Northern Flickers only work when they have to: how individual traits, population size and landscape disturbances affect excavation rates of an ecosystem engineer. Journal of Avian Biology 48(3):431-438. https://doi.org/10.1111/ jav. 01180

Zenner, E. K. 2004. Does old-growth condition imply high livetree structural complexity? Forest Ecology and Management 195 (1):243-258. https://doi.org/10.1016/j.foreco.2004.03.026

Zheng, Z., S. Zhang, C. Baskin, J. Baskin, D. Schaefer, X. Yang, and L. Yang. 2016. Hollows in living trees develop slowly but considerably influence the estimate of forest biomass. Functional Ecology 30: 830-838. https://doi.org/10.1111/1365-2435.12566

Zhu, X., D. S. Srivastava, J. N. M. Smith, and K. Martin. 2012. Habitat selection and reproductive success of Lewis's Woodpecker (Melanerpes lewis) at its northern limit. PLOS ONE 7(9):e44346. https://doi.org/10.1371/journal.pone.0044346 